Article

\title{
A Micro Electrochemical Sensor for Multi-Analyte Detection Based on Oxygenated Graphene Modified Screen-Printed Electrode
}

\author{
Baiqing Yuan *(D), Liju Gan, Gang Li, Chunying Xu and Gang Liu *(C) \\ School of Chemistry and Materials Science, Ludong University, Yantai 264025, China; \\ gan17737233930@163.com (L.G.); 1258331922@126.com (G.L.); chunyingxu@126.com (C.X.) \\ * Correspondence: bqyuan@ldu.edu.cn (B.Y.); shdliugang@163.com (G.L.)
}

check for

updates

Citation: Yuan, B.; Gan, L.; Li, G.;

Xu, C.; Liu, G. A Micro

Electrochemical Sensor for

Multi-Analyte Detection Based on

Oxygenated Graphene Modified

Screen-Printed Electrode.

Nanomaterials 2022, 12, 711 .

https://doi.org10.3390/

nano12040711

Academic Editor: Seung Hwan Ko

Received: 20 January 2022

Accepted: 17 February 2022

Published: 21 February 2022

Publisher's Note: MDPI stays neutral with regard to jurisdictional claims in published maps and institutional affiliations.

Copyright: () 2022 by the authors Licensee MDPI, Basel, Switzerland. This article is an open access article distributed under the terms and conditions of the Creative Commons Attribution (CC BY) license (https:// creativecommons.org/licenses/by/ $4.0 /)$.

\begin{abstract}
Electrode interfaces with both antibiofouling properties and electrocatalytic activity can promote the practical application of nonenzymatic electrochemical sensors in biological fluids. Compared with graphene, graphene oxide (GO) possesses unique properties such as superior solubility (hydrophilicity) in water, negative charge, and abundant oxygenated groups (oxo functionalities) in the plane and edge sites, which play an essential role in electrocatalysis and functionalization. In this work, a micro electrochemical sensor consisting of GO-modified screen-printed electrode and PDMS micro-cell was designed to achieve multi-analyte detection with excellent selectivity and anti-biofouling properties by electrochemically tuning the oxygen-containing functional species, hydrophilicity/hydrophobicity, and electrical conductivity. In particular, the presented electrodes demonstrated the potential in the analysis of biological samples in which electrodes often suffer from serious biofouling. The interaction of proteins with electrodes as well as uric acid was investigated and discussed.
\end{abstract}

Keywords: micro electrochemical sensor; multi-analyte detection; graphene oxide (GO); biofouling; oxo functionalities

\section{Introduction}

Electrochemical sensing represents a potential tool to perform clinical applications due to its low cost, simplicity and high selectivity and sensitivity. However, when the electrodes are exposed to biological fluids such as plasma or blood, biofouling often occurs due to the non-specific absorption of biological macromolecules, especially proteins, which hinders the electron transfer and thus results in a rapid loss of sensitivity [1,2]. This issue could be solved for the glucose meter combination with a semi-permeable membrane, in which small-molecule glucose could diffuse through the semi-permeable membrane and reach the electrode, but not for macromolecule proteins [3]. In addition to the enzyme and affinity-based electrochemical sensors, nonenzymatic electrochemical sensors coupled with antibiofouling strategies would be a promising commercial tool used in clinical analysis for small and electroactive biological molecules which are related to human health, such as uric acid (UA), ascorbic acid (AA), dopamine (DA), guanine (G) and adenine (A). In addition, voltammetry demonstrates high selectivity and thus could be used for multi-analyte measurements. Many chemical and physical strategies have been reported to alleviate the biofouling issues, including nanoengineered surfaces (i.e., nanoporous metals and nanocarbons), antifouling layers (PEG, zwitterionic polymers, and biopolymers), nanoporous membranes, and hydrogels [4]. For example, a nanoporous gold (NPG) electrode derived from the dealloying of a silver-gold alloy was recently employed as an antibiofouling electrode for the simultaneous determination of AA and UA [5]. However, the construction of these antibioflouling electrodes is often cumbersome and complex. It would be interesting if an electrode material possessed both excellent antibiofouling performance and high electrocatalytic activity toward these molecules. 
Graphene oxide (GO) is a complex carbon-based macromolecule that has a twodimensional (2D) structure and possesses abundant oxygen-containing functional species and hydrogen atoms on its basal plane and edges. Many models have been demonstrated to elucidate the structure of GO with dazzling confusion. Recently, Siaj et al. [6] overviewed all the aspects of GO structures and presented a precise structure clarifying the chemical nature of $\mathrm{GO}$ based on earlier and more modern models and new discoveries by other top researchers. The structural model comprises the presence of double bond $(\mathrm{C}=\mathrm{C})$, aromatic entity, epoxyl (C-O-C), hydroxy $(\mathrm{C}-\mathrm{OH})$, carboxylic acid $(\mathrm{O}=\mathrm{C}-\mathrm{OH}$ or salt), ketone $(\mathrm{C}=\mathrm{O})$, organic carbonate, phenol, quinone, lactol, ester carbonyl, carbon vacancies, sulfate ester, carbon radicals, implicit carbon-hydrogen bond (C-H), and allylic alcohol [6]. GO exhibits excellent water dispersity and hydrophilicity due to the ionizable edge $\mathrm{O}=\mathrm{C}-\mathrm{OH}$ species. In fact, carboxylic acid distributes at the edges while phenol hydroxyl and epoxide groups mainly present on the basal plane, endowing GO an amphiphile with hydrophilic edges and a more hydrophobic basal plane [7]. The versatile surface chemistry also offers GO a powerful platform for further construction with various chemical moieties (organic, inorganic, and nanocomposites) by covalent and noncovalent interactions [8].

Unfortunately, these oxo functionalities present on GO result in poor conductivity. In efforts tailoring GO with high conductivity for applications in electrochemistry and electronics, tremendous efforts have been directed toward the elimination of the oxidized functionalities from GO by means of microorganisms, chemicals, electrochemistry, heat, $\mathrm{UV}$, microwave irradiation, ion bombardments or multiphase methods [9-11]. Although the removal of oxygen-containing functional species increases the conductivity of the $2 \mathrm{D}$ material, it was recently found that the residual oxo functionalities play an essential role in promoting the electrocatalytic reaction. For example, mildly reduced GO with high concentrations of epoxy or ring ether groups located either on their basal planes or at plane edges exhibit excellent activity, high selectivity and stability for electrochemical $\mathrm{H}_{2} \mathrm{O}_{2}$ production from oxygen [12,13]. Furthermore, carbon defects related to quinone/catechol groups or carboxylic acid edge sites play a more pivotal role in boosting $2 \mathrm{e}^{-}$ORR peroxide formation activity than other oxygen-containing functional species under alkaline conditions for nitrogen-doped reduced GO [14]. The residual oxygen-containing functional species present on graphene also enhanced the electrocatalytic oxidation of glutathione [15], dihydroxybenzene isomers, L-methionine [16], and ascorbic acid [17], as well as the reduction of polyphenol [18].

It has been proved that electrochemical reduction is an ideal method to tune both conductivity and electrocatalytic activity of GO under different degrees of reduction [19]. Here, electrochemically tuned GO was explored for the electrochemical sensing of multianalytes, and the effect of oxygen-containing functional species on both electrocatalysis and antibiofouling ability was also investigated in detail. The results showed that the residual oxo functionalities were beneficial for the selectivity and electro-oxidation of UA, DA, AA, $\mathrm{G}$ and $\mathrm{A}$. In addition, the oxo functionalities were responsible for the binding of proteins in serum, which forms a coating layer. The binding layer facilitated the mass transport and did not hinder the electron transfer of electroactive probe $\mathrm{Fe}(\mathrm{CN})_{6}{ }^{4-} / \mathrm{Fe}(\mathrm{CN})_{6}{ }^{3-}$.

\section{Experimental Section}

\subsection{Chemicals and Solutions}

Bovine Serum Albumin (BSA), UA, DA, AA, G, A, and Polydimethylsiloxanes (PDMS) were purchased from Sigma-Aldrich (St. Louis, MO, USA). GO was purchased from Nanjing XFNano Materials Tech Co., Ltd (Nanjing, Jiangsu, China). The screen-printed electrodes (DRP 110) were purchased from DROPSENS (Oviedo, Spain). All other chemicals were of analytical reagent grade and used without further purification. The aqueous solutions were prepared with doubly distilled water. An amount of $0.1 \mathrm{M} \mathrm{pH}=7.2 \mathrm{PBS}$ solution was used as the background electrolyte for measurements. The oxo functionalities present on GO were tuned by electrochemical treatment for $500 \mathrm{~s}$ at different potentials from -0.6 to $-1.2 \mathrm{~V}$ using an I-T curve in acetic buffer $(\mathrm{pH}=4)$. The electrochemical tuned 
$\mathrm{GO}$ electrode was signed as $\mathrm{GO}_{\text {potential }}$. For example, $\mathrm{GO}_{-0.75 \mathrm{~V}}$ refers to the $\mathrm{GO}$ electrode that was electrochemically treated at $-0.75 \mathrm{~V}$. Unless otherwise specified, $\mathrm{GO}_{-0.75 \mathrm{~V}}$ was used in the text.

\subsection{Apparatus}

The X-ray photoelectron spectroscopy (XPS) was recorded on a Thermo ESCALAB 250 Xi spectrometer fitted with a monochromatic Al K $\alpha$ X-ray source. The morphologies were characterized by scanning electron microscopy (SEM) (Hitachi SU8010). All the electrochemical experiments were carried out with a CHI 750E electrochemical workstation with a conventional three-electrode system consisting of a modified GCE working electrode or screen-printed electrode, platinum coil auxiliary electrode, and $\mathrm{Ag} / \mathrm{AgCl}$ (saturated $\mathrm{KCl}$ ) reference electrode. Differential pulse voltammetry technology was used for electrochemical detection. Electrochemical impedance spectra (EIS) were carried out in $0.1 \mathrm{M} \mathrm{KCl}$ containing $5 \mathrm{mM} \mathrm{Fe}(\mathrm{CN})_{6}{ }^{3-/ 4-}$ in the frequency range of $1 \mathrm{MHz}$ to $0.1 \mathrm{~Hz}$ at $0.24 \mathrm{~V}$.

The screen-printed electrode modified with $\mathrm{GO}_{-0.75 \mathrm{~V}}$ was integrated with a PDMSbased micro electrochemical cell for the analysis of five biological molecules and serum (Schemes 1 and 2). In order to prevent the leaking of the solution, two powerful magnets were used to compress the cell together with the electrode. The micro PDMS cell was fabricated according to Scheme 2 in four steps, including mold construction, casting with PDMS mixture, baking, and mold removal. Two well-cut plastic tubes were concentrically fixed. The outer tube was sealed to a flat glass with instant adhesive. The inner tube was fixed on a screen-printed electrode template with adhesive, which was inserted through the sidewall of the outer tube and adhered to. The proper amount of degassed mixture of PDMS monomer and curing agent (in a 10:1 ratio) was poured into the ring part, followed by baking for $40 \mathrm{~min}$ at $100{ }^{\circ} \mathrm{C}$. Finally, PDMS was peeled from the mold, and the cell body was obtained.

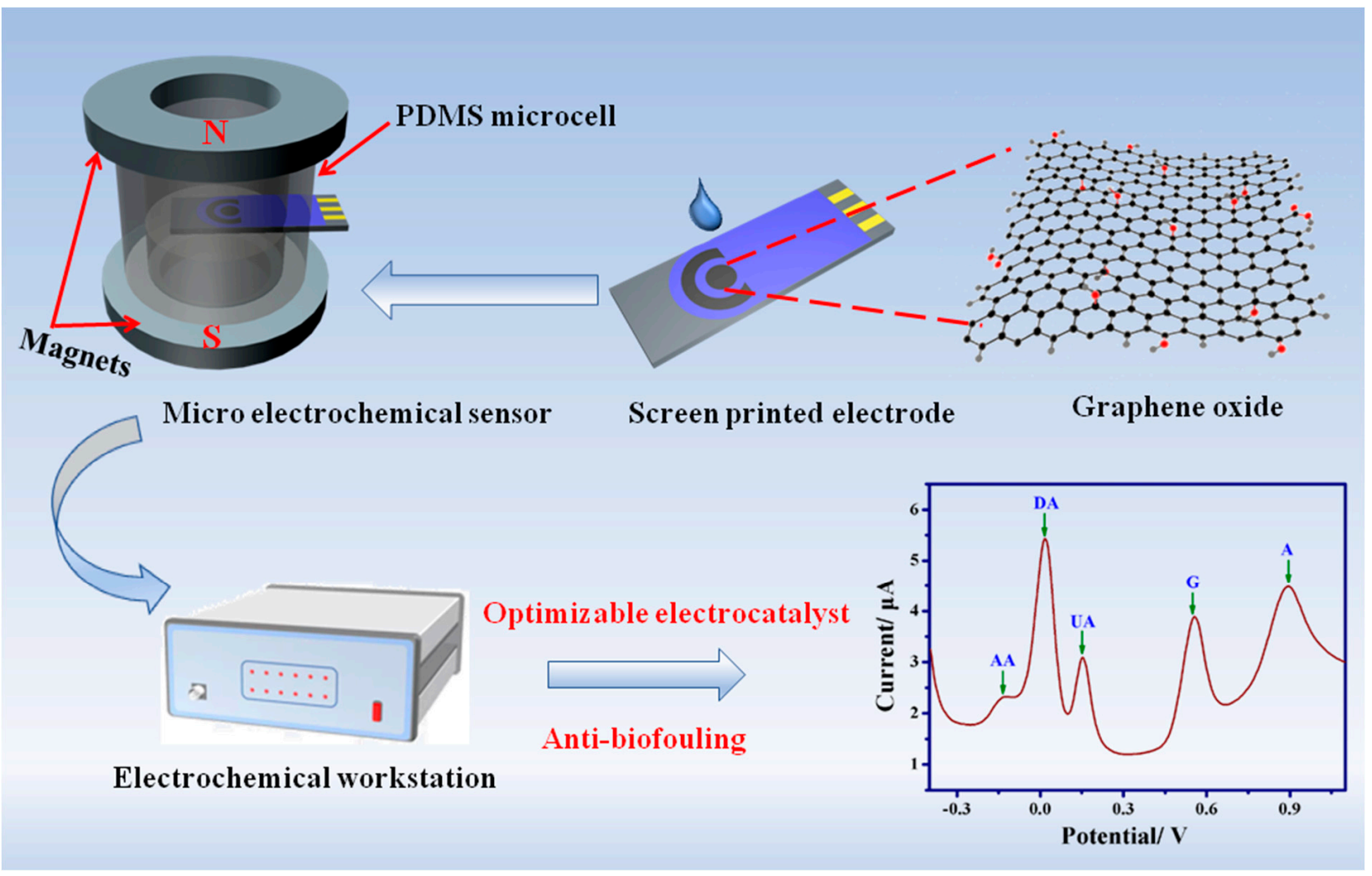

Scheme 1. Electrochemical sensing of multi-analyte based on electrochemically tuned GO electrode. 

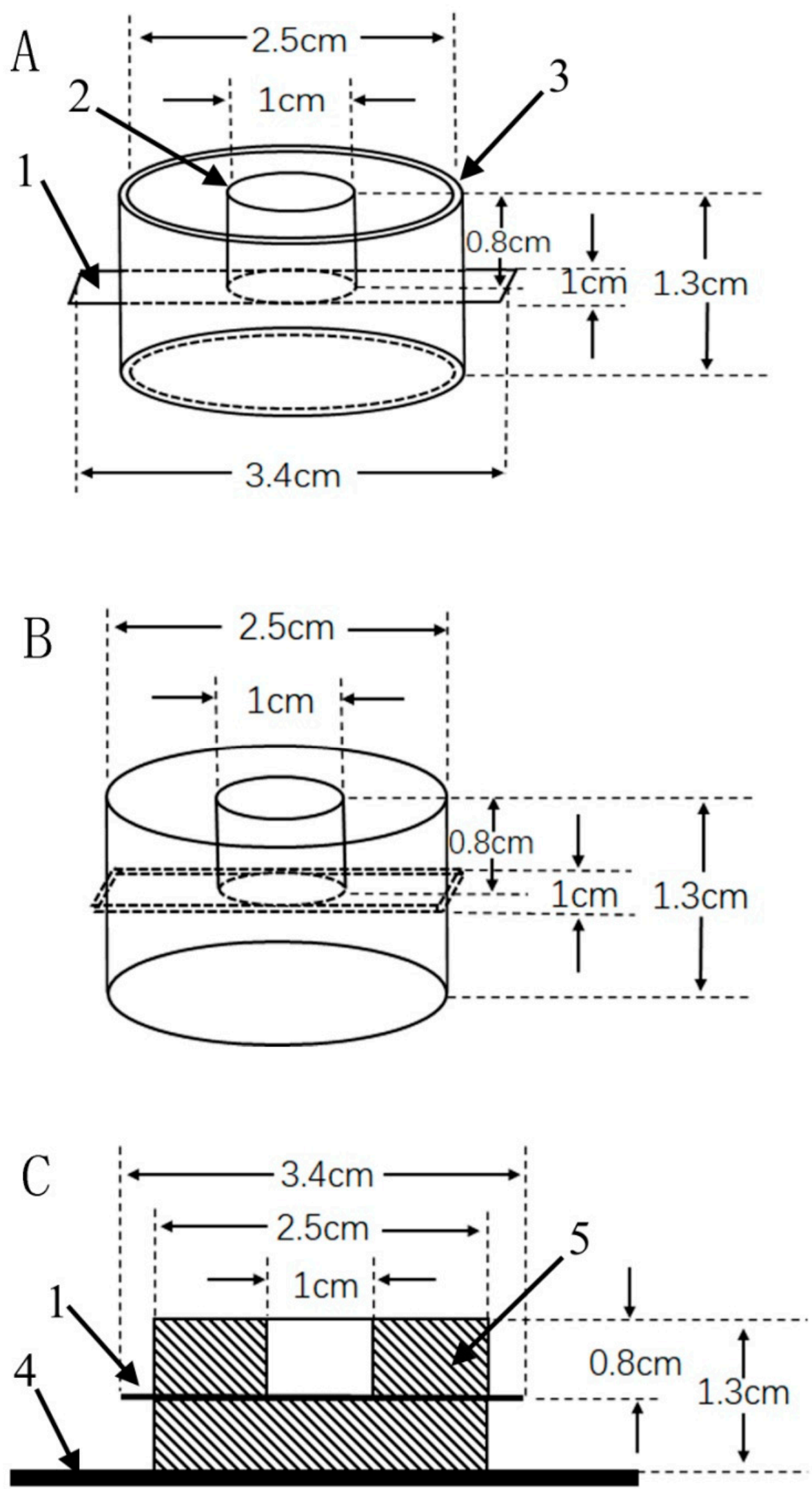

Scheme 2. Preparation of the PDMS-based micro-cell. (A) Mold construction: (1) screen-printed electrode template, $(2,3)$ two cut plastic tubes. (B) Schematic view of obtained PDMS micro-cell. (C) A cross-sectional view of PDMS micro-cell used for detection: (1) screen-printed electrode template, (4) glass plate, (5) PDMS cell body. 


\subsection{Electrode Preparation and Modification}

Prior to modification, the GCE (3 $\mathrm{mm}$ diameter, $0.07 \mathrm{~cm}^{2}$ ) was successively polished with $1,0.3$, and $0.05 \mu \mathrm{m}$ alumina paste to a mirror finish and then rinsed with water followed by an ultrasonic treatment in water and ethanol, respectively. The GO-modified GCE (GO/GCE), or screen-printed electrode, was prepared by dropping $5 \mu \mathrm{L}$ or $7 \mu \mathrm{L}$ GO suspension $(1 \mathrm{mg} / \mathrm{mL})$ on a cleaned GCE and left to dry at room temperature.

\subsection{Interaction between Electrode and Proteins}

In order to study the interaction between the electrode and BSA, GO/GCE or GO-0.75V/GCE was immersed in $10 \mathrm{mg} / \mathrm{mL}$ BSA solution for $30 \mathrm{~min}$, and the dipped electrode was signed with GO-BSA or $\mathrm{GO}_{-0.75 \mathrm{~V}}$-BSA. In addition, GO/GCE or $\mathrm{GO}_{\text {potential }}$

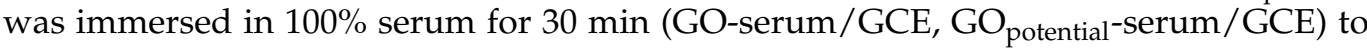
investigate the antibiofouling property. The interaction between BSA and UA was tested by immersing the electrode in $10 \mathrm{mg} / \mathrm{mL}$ BSA solution for $30 \mathrm{~min}$ and then rinsing with water, followed by dipping in $200 \mu \mathrm{M}$ UA for $30 \mathrm{~min}\left(\mathrm{GO}_{-0.75 \mathrm{~V}}\right.$-BSA-UA/GCE).

\subsection{Serum Sample Analysis for $U A$}

An original human serum sample was diluted with PBS at a 1:40 v/v ratio for measurements without any other pretreatment.

\section{Results and Discussion}

\subsection{XPS Characterization of the Oxo Functionalities Present on $G O_{\text {potential }}$}

Over-reduction of GO will lose oxo functionalities, which have been proved to be beneficial for electrocatalysis. Good balance of conductivity and oxo functionalities of GO would play an important part in nonenzymatic electrochemical sensing. XPS was used for the analysis of oxo functionalities present on GO which was electrochemically treated at different potentials from -0.6 to $-1 \mathrm{~V}$. Figure 1 shows the recorded C1s spectra of XPS for electrochemically treated GO/GC. Different functional species, including $\mathrm{C}=\mathrm{C}, \mathrm{C}-\mathrm{C}$, $\mathrm{C}-\mathrm{OH}, \mathrm{C}-\mathrm{O}-\mathrm{C}, \mathrm{C}=\mathrm{O}$, and $\mathrm{O}-\mathrm{C}=\mathrm{O}$, were observed [19]. In order to quantify the change in different components, the content of different functionalities present on $\mathrm{GO}_{\text {potential versus }}$ potential is shown in Figure 2. It could be seen in Figure 2A, with the negative shift of the potential, the content of both $\mathrm{C}=\mathrm{O}$ and $\mathrm{C}-\mathrm{O}-\mathrm{C}$ showed a downward trend, and $\mathrm{C}=\mathrm{O}$ species disappeared when the potential was much lower than $-0.8 \mathrm{~V}$. The content of both $\mathrm{C}-\mathrm{OH}$ and $\mathrm{O}-\mathrm{C}=\mathrm{O}$ species increased until $-0.85 \mathrm{~V}$, which might be attributed to the reduction of $\mathrm{C}=\mathrm{O}$, and then decreased when the potential was much lower than $-0.85 \mathrm{~V}$, indicating the reduction of the $\mathrm{C}-\mathrm{OH}$ and $\mathrm{O}-\mathrm{C}=\mathrm{O}$ species [19].

\subsection{Electrochemical Sensing of Multiple-Analyte}

Electrochemically treated GO at different potentials was explored for the electrocatalytic oxidation of UA, DA and AA. These three molecules are electrooxidizable constituents that are commonly present in physiological fluids. It is hard to achieve efficient discrimination from each other by voltammetry due to their overlapped oxidation potential. Figure 3 shows the DPV of the mixture of $200 \mu \mathrm{M}$ AA, $20 \mu \mathrm{M}$ DA, and $20 \mu \mathrm{M}$ UA in $0.1 \mathrm{M} \mathrm{pH}$ 7.2 PBS at different electrodes. Only one oxidation peak was observed for bare GCE, and two oxidation waves appeared for GO/GCE. However, when GO was electrochemically treated even at $-0.6 \mathrm{~V}$, three oxidation peaks with high selectivity occurred, indicating improved electrocatalytic activity. With the negative shift of the potential, the oxidation current increased until $-0.75 \mathrm{~V}$. Nevertheless, electrochemical treatment at more negative potential than $-0.75 \mathrm{~V}$ would lead to decreased selectivity. This might be caused by the loss of oxo functionalities.

Although the over-electro-reduction of GO can improve the conductivity, useful oxo functionalities will be lost, which may be beneficial for electrocatalysis and selectivity. Conductivity, electro-active sites and binding interaction play an important part in electrochemical sensing. At $\mathrm{pH}=7.2$, UA exists in the anionic form ( $\mathrm{pKa}=5.4)$, which is more 
hydrophobic than AA and DA due to its very limited solubility in water [20]. AA exists as an anion $(\mathrm{pKa}=4.10)$ while $\mathrm{DA}$ is in the cationic form $(\mathrm{pKb}=8.87)$ [21]. Among these oxo functionalities present on $\mathrm{GO}$, ionizable $\mathrm{O}=\mathrm{C}-\mathrm{OH}$ species distributes at the edges, while phenol hydroxyl and epoxide groups mainly present on the basal plane, leading to an edge-to-center distribution of hydrophilic and hydrophobic domains. Pristine GO/GCE exhibited much higher selectivity than bare GCE, suggesting that the oxo functionalities might interact with the analyte and consequently lead to enhanced selectivity, even though GCE has much higher conductivity than pristine GO. In summary, we speculated that the enhanced selectivity was attributed to the hydrophobic interaction between the electrode and $\mathrm{UA}$ and the electrostatic force between $\mathrm{O}=\mathrm{C}-\mathrm{OH}$ species and DA. In addition, conductivity and electrocatalytic activity from $\mathrm{C}=\mathrm{O}$ species might also play an important role in the electrochemical behavior of UA, DA and AA.
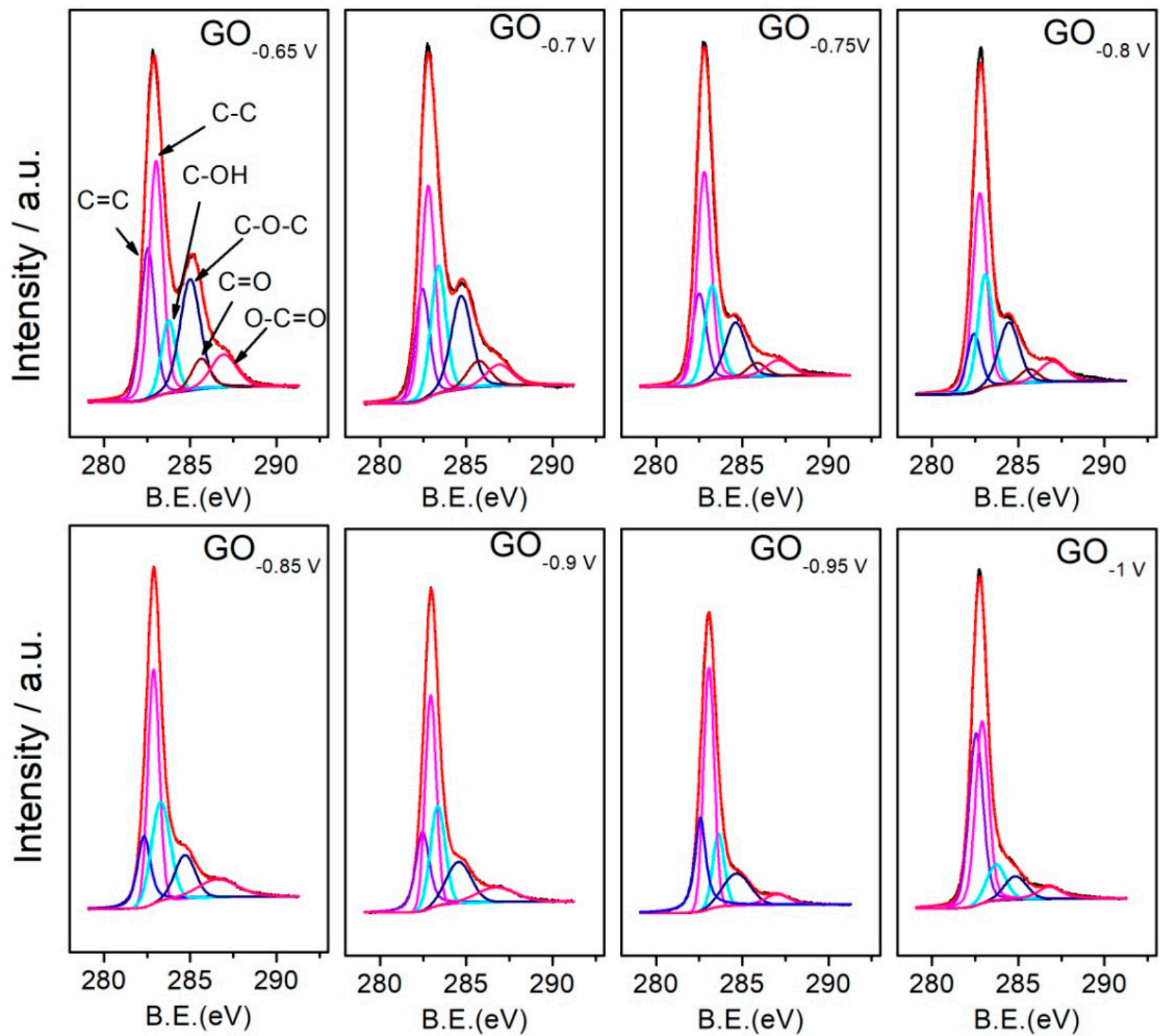

Figure 1. XPS narrow scan of the $\mathrm{C} 1$ s region for electrochemically treated GO/GCE at different potentials. 

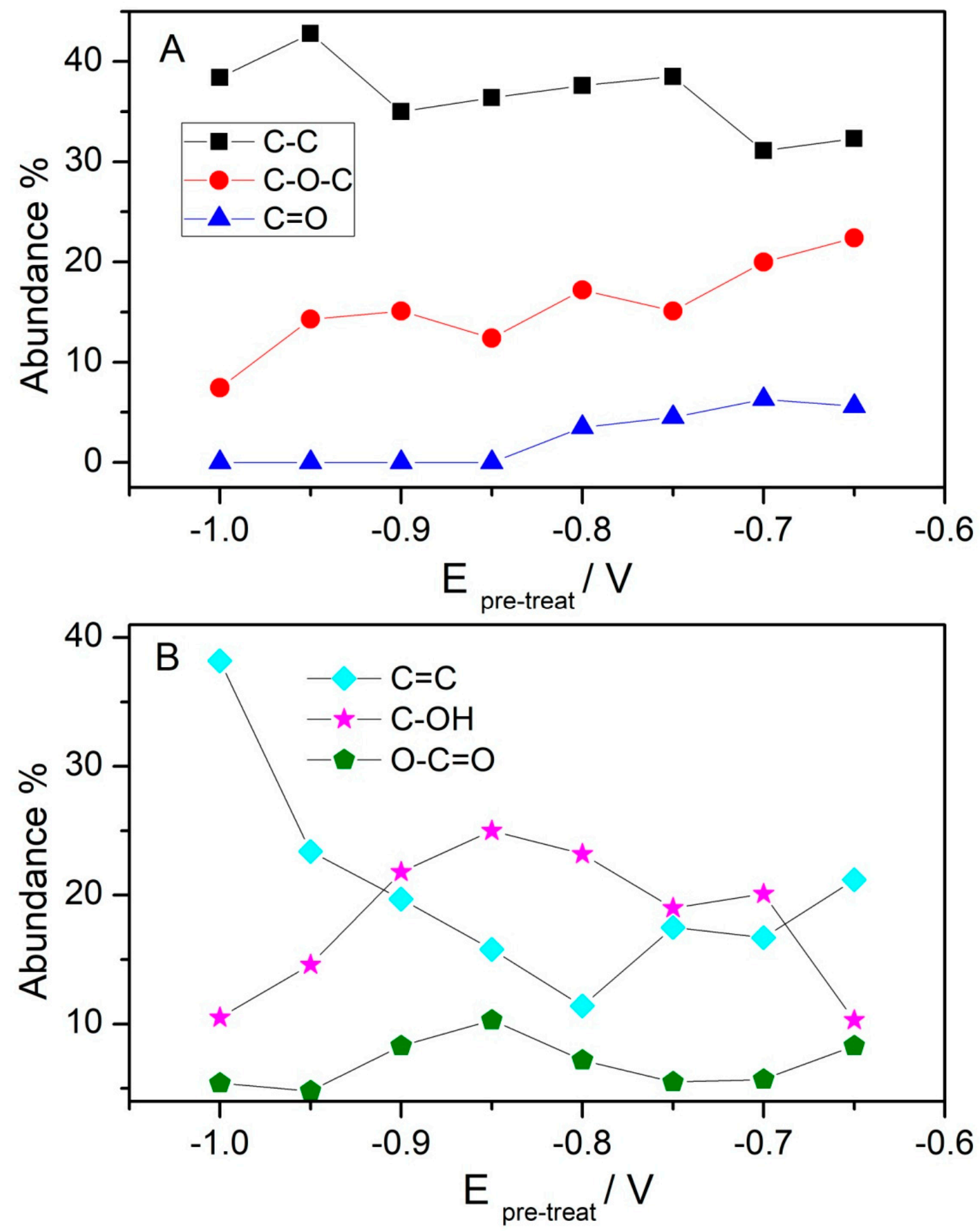

Figure 2. Abundance amount of different functionalities present on $\mathrm{GO}$ electrochemically treated at different potentials. (A): C-C, C-O-C and $\mathrm{C}=\mathrm{O} ;(\mathbf{B})$ : $\mathrm{C}=\mathrm{C}, \mathrm{C}-\mathrm{OH}$ and $\mathrm{O}-\mathrm{C}=\mathrm{O}$.

Under optimum conditions, $\mathrm{GO}_{-0.75 \mathrm{~V}} / \mathrm{GCE}$ was employed for the electrochemical detection of UA in the presence of AA and DA in $0.1 \mathrm{M} \mathrm{pH}$ 7.2 PBS (Figure S1). Linear calibration curves are obtained over the range of $0.2-20 \mu \mathrm{M}$ with the calculated detection limit of $0.12 \mu \mathrm{M}$. Similarly, Figure S2 demonstrates the electrochemical detection of DA in the presence of AA and UA and gives a linear dependence of the peak current for DA with concentrations ranging from 1 to $100 \mu \mathrm{M}$ with the calculated detection limit of $0.5 \mu \mathrm{M}$. 
Electrochemically treated GO at different potentials was also demonstrated for the electrocatalytic oxidation of G and A (Figure S3). GCE showed two anodic waves located at 0.63 and $0.97 \mathrm{~V}$, respectively. For pristine GO-modified electrodes, the two peaks shift to 0.61 and $0.93 \mathrm{~V}$, respectively. When the potential shifted negatively, the oxidation potential of $\mathrm{G}$ and A decreased gradually until $-0.75 \mathrm{~V}$. The oxidation peak of $\mathrm{G}$ and A shifted to 0.55 and $0.85 \mathrm{~V}$ at $\mathrm{GO}_{-0.75 \mathrm{~V}} / \mathrm{GCE}$, respectively. The decreased overpotential of $\mathrm{G}$ and $\mathrm{A}$ indicated the enhanced electrocatalytic activity, which is the result of the balance of conductivity and some oxo functionalities as seen in $\mathrm{C}=\mathrm{O}$ species. Upon the potential beyond $-0.75 \mathrm{~V}$, the background noise increased. Therefore, $\mathrm{GO}_{-0.75 \mathrm{~V}} / \mathrm{GCE}$ was selected for the electrochemical measurements. Figures S4 and S5 present the electrochemical detection of G and A in $0.1 \mathrm{M}$ pH 7.2 PBS, respectively. The calibration plot shows that the peak current of A (or G) exhibits a linear relationship $\left(R^{2}=0.998\right.$ or 0.999$)$ over a concentration range from $2 \mu \mathrm{M}$ to $100 \mu \mathrm{M}(0.5$ to $100 \mu \mathrm{M})$ with a detection limit of $0.3 \mu \mathrm{M}(0.2 \mu \mathrm{M})$. Table 1 lists the electrochemical sensing performances for five biological molecules based on $\mathrm{GO}_{-0.75 \mathrm{~V}}$ and other electrocatalysts. The results showed that this method exhibited a comparable linear range and detection limit with other electrocatalysts.

Next, this method was demonstrated to selectively discriminate UA, DA, AA, G, and A by using a $\mathrm{GO}_{-0.75 \mathrm{~V}}$-modified screen-printed electrode couple with a homemade PDMS micro electrochemical cell (Figure 4). The results showed that the electrode exhibited high-resolution discrimination for five biological molecules.

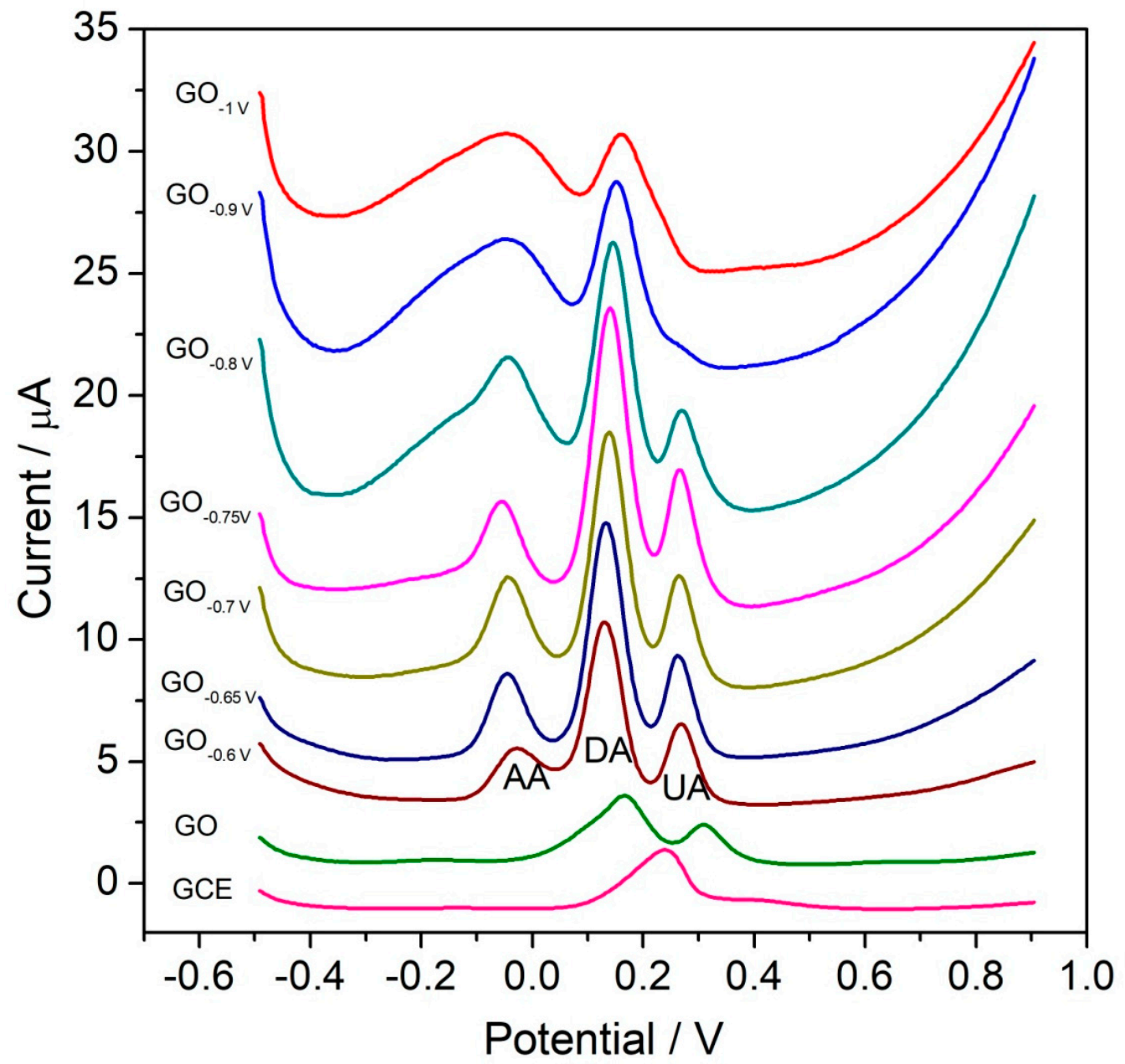

Figure 3. DPV of the mixture of $200 \mu \mathrm{M}$ AA, $20 \mu \mathrm{M}$ DA, and $20 \mu \mathrm{M}$ UA in $0.1 \mathrm{M} \mathrm{pH} 7.2 \mathrm{PBS}$ at the GCE, GO, and GO/GCE electrochemically treated at different potentials. Conditions: Inc E, $4 \mathrm{mV}$; Amplitude, 0.05 V; Pulse width, 0.2 s; Sample width, 0.0167 s; Pulse period, 0.5 s. 
Table 1. Electrochemical sensing performances for five biological molecules based on $\mathrm{GO}_{-0.75 \mathrm{~V}}$ and other electrocatalysts.

\begin{tabular}{|c|c|c|c|c|c|}
\hline Electrocatalysts & Linear Range & Detection Limit & $\mathrm{pH}$ & Samples & Ref. \\
\hline PrGO/PB & & $\begin{array}{l}\text { AA: } 34.7 \mu \mathrm{M} \\
\text { DA: } 26.2 \mu \mathrm{M} \\
\text { UA: } 8.0 \mu \mathrm{M}\end{array}$ & 7.4 & & [22] \\
\hline TiN-rGO & $\begin{array}{c}\text { AA: } 50-100 \mu \mathrm{M} \\
\text { DA: } 5-175 \mu \mathrm{M} \\
\text { UA: } 30-215 \mu \mathrm{M}\end{array}$ & $\begin{array}{c}\text { AA: } \\
\text { DA: } 0.159 \mu \mathrm{M} \\
\text { UA: } 0.350 \mu \mathrm{M}\end{array}$ & 7.0 & spiked in urine & [23] \\
\hline PVP-GR & $\begin{array}{l}\text { AA: } 4.0-1000 \mu \mathrm{M} \\
\text { DA: } 0.02-100 \mu \mathrm{M} \\
\text { UA: } 0.04-100 \mu \mathrm{M}\end{array}$ & $\begin{array}{c}\text { AA: } 0.8 \mu \mathrm{M} \\
\text { DA: } 0.002 \mu \mathrm{M} \\
\text { UA: } 0.02 \mu \mathrm{M}\end{array}$ & 6.0 & urine & [24] \\
\hline h-BN & $\begin{array}{c}\text { AA: } 30-1000 \mu \mathrm{M} \\
\text { DA: } 0.5-150 \mu \mathrm{M} \\
\text { UA: } 1-300 \mu \mathrm{M}\end{array}$ & $\begin{array}{l}\text { AA: } 3.77 \mu \mathrm{M} \\
\text { DA: } 0.02 \mu \mathrm{M} \\
\text { UA: } 0.15 \mu \mathrm{M}\end{array}$ & 6.0 & spiked in urine & [25] \\
\hline $\mathrm{PrGO} / \mathrm{MnO}_{2}$ & $\begin{array}{c}\text { AA: } 1-800 \mu \mathrm{M} \\
\text { DA: } 0.03-45 \mu \mathrm{M} \\
\text { UA: } 0.3-80 \mu \mathrm{M}\end{array}$ & $\begin{array}{l}\text { AA: } 1.00 \mu \mathrm{M} \\
\text { DA: } 0.02 \mu \mathrm{M} \\
\text { UA: } 0.05 \mu \mathrm{M}\end{array}$ & 6.0 & spiked in urine & [26] \\
\hline $\mathrm{CNP}$ & $\begin{array}{l}\text { AA: } 20-250 \mu \mathrm{M} \\
\text { DA: } 10-480 \mu \mathrm{M} \\
\text { UA: } 25-2500 \mu \mathrm{M}\end{array}$ & $\begin{array}{l}\text { AA: } 4.25 \mu \mathrm{M} \\
\text { DA: } 0.86 \mu \mathrm{M} \\
\text { UA: } 0.20 \mu \mathrm{M}\end{array}$ & 7.0 & spiked in serum & [27] \\
\hline N-rGO & $\begin{array}{l}\text { AA: } 0.1-4 \mu \mathrm{M} \\
\text { DA: } 1-60 \mu \mathrm{M} \\
\text { UA: } 1-30 \mu \mathrm{M}\end{array}$ & $\begin{array}{l}\text { AA: } 9.6 \mu \mathrm{M} \\
\text { DA: } 0.1 \mu \mathrm{M} \\
\text { UA: } 0.2 \mu \mathrm{M}\end{array}$ & 7.0 & & [28] \\
\hline RGO/AuNPs & & $\begin{array}{c}\text { AA: } 9.5 \mu \mathrm{M} \\
\text { DA: } 0.14 \mu \mathrm{M} \\
\text { UA: } 25 \mu \mathrm{M}\end{array}$ & 7.4 & & [29] \\
\hline $\mathrm{MNP} / \mathrm{rGO} / \mathrm{GCE}$ & $\begin{array}{c}\text { AA: } 10-100 \mu \mathrm{M} \\
\text { DA: } 15 \mathrm{~nm}-100 \mu \mathrm{M} \\
\text { UA: } 10-100 \mu \mathrm{M}\end{array}$ & $\begin{array}{c}\text { AA: } 0.22 \mu \mathrm{M} \\
\text { DA: } 0.19 \mathrm{nM} \\
\text { UA: } 45 \mathrm{nM}\end{array}$ & & & [30] \\
\hline ERGO-pEBT & $\begin{array}{c}\text { AA: } 10-900 \mu \mathrm{M} \\
\text { DA: } 0.5-20 \mu \mathrm{M} \\
\text { UA: } 2-70 \mu \mathrm{M}\end{array}$ & $\begin{array}{l}\text { AA: } 0.53 \mu \mathrm{M} \\
\text { DA: } 0.009 \mu \mathrm{M} \\
\text { UA: } 0.046 \mu \mathrm{M}\end{array}$ & 6.0 & urine & [31] \\
\hline N-rGO & $\begin{array}{c}\text { AA: } 550-1500 \mu \mathrm{M} \\
\text { DA: 3-100 } \mu \mathrm{M} \\
\text { UA: } 20-1000 \mu \mathrm{M}\end{array}$ & $\begin{array}{c}\text { AA: } 58 \mu \mathrm{M} \\
\text { DA: } 2.4 \mu \mathrm{M} \\
\text { UA: } 8.7 \mu \mathrm{M}\end{array}$ & 7.4 & & [32] \\
\hline HCONS & $\begin{array}{c}\text { AA: } 12.5-1382 \mu \mathrm{M} \\
\text { DA: } 1.6-23.6 \mu \mathrm{M} \\
\text { UA: } 46.5-806.5 \mu \mathrm{M}\end{array}$ & $\begin{array}{c}\text { AA: } 12.5 \mu \mathrm{M} \\
\text { DA: } 0.012 \mu \mathrm{M} \\
\text { UA: } 1.5 \mu \mathrm{M}\end{array}$ & 7.4 & serum & [33] \\
\hline $\mathrm{Ni@CHS/rGO}$ & $\begin{array}{c}\text { AA: } 2-4000 \mu \mathrm{M} \\
\text { DA: } 0.25-126 \mu \mathrm{M} \\
\text { UA: } 0.25-126 \mu \mathrm{M}\end{array}$ & $\begin{array}{l}\text { AA: } 0.37 \mu \mathrm{M} \\
\text { DA: } 0.05 \mu \mathrm{M} \\
\text { UA: } 0.05 \mu \mathrm{M}\end{array}$ & 7.0 & spiked in urine & [34] \\
\hline $\mathrm{MoS}_{2}$-PGE & $\begin{array}{l}\text { G: } 15-120 \mu \mathrm{M} \\
\text { A: } 15-120 \mu \mathrm{M}\end{array}$ & $\begin{array}{l}\mathrm{G}: 0.76 \mu \mathrm{M} \\
\mathrm{A}: 2.38 \mu \mathrm{M}\end{array}$ & 7.4 & & [35] \\
\hline $\begin{array}{c}\text { PPyox/MWNTs- } \\
\mathrm{MoS}_{2} / \mathrm{GCE}\end{array}$ & $\begin{array}{c}\text { G: } 5-30 \mu \mathrm{M} \\
\text { A: } 30-120 \mu \mathrm{M}\end{array}$ & $\begin{array}{l}\mathrm{G}: 1.6 \mu \mathrm{M} \\
\mathrm{A}: 1.7 \mu \mathrm{M}\end{array}$ & 7.0 & salmon sperm DNA & [36] \\
\hline $\mathrm{Cu} @ \mathrm{Ni} / \mathrm{MWCNTs}$ & $\begin{array}{l}\text { G: } 5-180 \mu \mathrm{M} \\
\text { A: } 8-150 \mu \mathrm{M}\end{array}$ & $\begin{array}{l}\mathrm{G}: 0.35 \mu \mathrm{M} \\
\mathrm{A}: 0.56 \mu \mathrm{M}\end{array}$ & 4.0 & $\begin{array}{l}\text { dsDNA from brain } \\
\text { tissue of mice }\end{array}$ & [37] \\
\hline $\begin{array}{c}\text { ds-DNA/ } \\
\mathrm{p}(\mathrm{L}-\mathrm{Cys}) / \mathrm{Fe}_{3} \mathrm{O}_{4} \\
\text { NPs-GO/CPE }\end{array}$ & $\begin{array}{l}\text { G: } 0.01-25 \mu \mathrm{M} \\
\text { A: } 0.01-30 \mu \mathrm{M}\end{array}$ & $\begin{array}{l}\mathrm{G}: 1.59 \mu \mathrm{M} \\
\mathrm{A}: 3.48 \mu \mathrm{M}\end{array}$ & 6.5 & blood DNA & [38] \\
\hline
\end{tabular}


Table 1. Cont.

\begin{tabular}{|c|c|c|c|c|c|}
\hline Electrocatalysts & Linear Range & Detection Limit & $\mathrm{pH}$ & Samples & Ref. \\
\hline p-GLY/GO & $\begin{array}{l}\text { G: } 0.15-48 \mu \mathrm{M} \\
\mathrm{A}: 0.09-103 \mu \mathrm{M}\end{array}$ & $\begin{array}{c}\text { G: } 0.026 \mu \mathrm{M} \\
\text { A: } 0.03 \mu \mathrm{M}\end{array}$ & 3.7 & $\begin{array}{l}\text { urine and fish } \\
\text { sperm DNA }\end{array}$ & [39] \\
\hline $\mathrm{PDA} / \mathrm{MnO}_{2} / \mathrm{IL}-\mathrm{G}$ & $\begin{array}{l}\text { G: } 10-300 \mu \mathrm{M} \\
\text { A: } 10-300 \mu \mathrm{M}\end{array}$ & $\begin{array}{l}\text { G: } 0.25 \mu \mathrm{M} \\
\text { A: } 0.15 \mu \mathrm{M}\end{array}$ & 4.0 & mouse whole blood & [40] \\
\hline $\mathrm{CuO}$ NPs & $\begin{array}{l}\mathrm{G}: 1-80 \mu \mathrm{M} \\
\mathrm{A}: 1-80 \mu \mathrm{M}\end{array}$ & $\begin{array}{l}\text { G: } 0.687 \mu \mathrm{M} \\
\text { A: } 0.472 \mu \mathrm{M}\end{array}$ & 7.0 & & {$[41]$} \\
\hline $\mathrm{COFS} / \mathrm{NH}_{2}-\mathrm{rG} / \mathrm{MoS}_{2}$ & $\begin{array}{c}\text { G: } 0.5-150 \mu \mathrm{M} \\
\text { A: } 1-280 \mu \mathrm{M}\end{array}$ & $\begin{array}{l}\text { G: } 0.51 \mu \mathrm{M} \\
\text { A: } 0.44 \mu \mathrm{M}\end{array}$ & 2.0 & herring sperm DNA & [42] \\
\hline $\mathrm{Au} / \mathrm{HG}$ & $\begin{array}{l}\text { G: } 6-500 \mu \mathrm{M} \\
\text { A: } 0.6-40 \mu \mathrm{M}\end{array}$ & $\begin{array}{l}\text { G: } 2.5 \mu \mathrm{M} \\
\text { A: } 0.42 \mu \mathrm{M}\end{array}$ & 7.0 & & [43] \\
\hline CQD/PAPox & $\begin{array}{l}\mathrm{G}: 1-65 \mu \mathrm{M} \\
\mathrm{A}: 2-70 \mu \mathrm{M}\end{array}$ & $\begin{array}{l}\mathrm{G}: 0.51 \mu \mathrm{M} \\
\mathrm{A}: 0.39 \mu \mathrm{M}\end{array}$ & 3.7 & fish sperm DNA & {$[44]$} \\
\hline $\begin{array}{c}\mathrm{Cu}-\mathrm{CeO}_{2} / \\
\mathrm{MWCNT} / \mathrm{GCE}\end{array}$ & $\begin{array}{l}\text { G: } 0.2-6 \mu \mathrm{M} \\
\text { A: } 0.1-8 \mu \mathrm{M}\end{array}$ & $\begin{array}{l}\mathrm{G}: 0.128 \mu \mathrm{M} \\
\mathrm{A}: 0.062 \mu \mathrm{M}\end{array}$ & 7.0 & a calf thymus DNA & [45] \\
\hline ZnS NPs /CPE & $\begin{array}{c}\text { G: } 1-15 \mu \mathrm{M} \\
\text { A: } 15-120 \mu \mathrm{M}\end{array}$ & $\begin{array}{l}\text { G: } 0.036 \mu \mathrm{M} \\
\text { A: } 0.031 \mu \mathrm{M}\end{array}$ & 7.4 & & [46] \\
\hline$\beta C D /$ IRGO & $\begin{array}{l}\text { G: } 0.03-10 \mu \mathrm{M} \\
\text { A: } 0.02-7 \mu \mathrm{M}\end{array}$ & $\begin{array}{l}\mathrm{G}: 0.01 \mu \mathrm{M} \\
\mathrm{A}: 0.01 \mu \mathrm{M}\end{array}$ & 7.0 & & {$[47]$} \\
\hline poly(dopamine)/GR & $\begin{array}{l}\mathrm{G}: 1-58 \mu \mathrm{M} \\
\mathrm{A}: 1-58 \mu \mathrm{M}\end{array}$ & $\begin{array}{l}\text { G: } 0.34 \mu \mathrm{M} \\
\mathrm{A}: 0.31 \mu \mathrm{M}\end{array}$ & 7.0 & a calf thymus DNA & {$[48]$} \\
\hline $\mathrm{GO}_{-0.75 \mathrm{~V}}$ & $\begin{array}{l}\text { DA: } 1-100 \mu \mathrm{M} \\
\text { UA: } 0.2-20 \mu \mathrm{M} \\
\text { G: } 0.5-100 \mu \mathrm{M} \\
\text { A: } 2-100 \mu \mathrm{M}\end{array}$ & $\begin{array}{c}\text { DA: } 0.5 \mu \mathrm{M} \\
\text { UA: } 0.12 \mu \mathrm{M} \\
\text { G: } 0.2 \mu \mathrm{M} \\
\text { A: } 0.3 \mu \mathrm{M}\end{array}$ & 7.2 & & This work \\
\hline
\end{tabular}

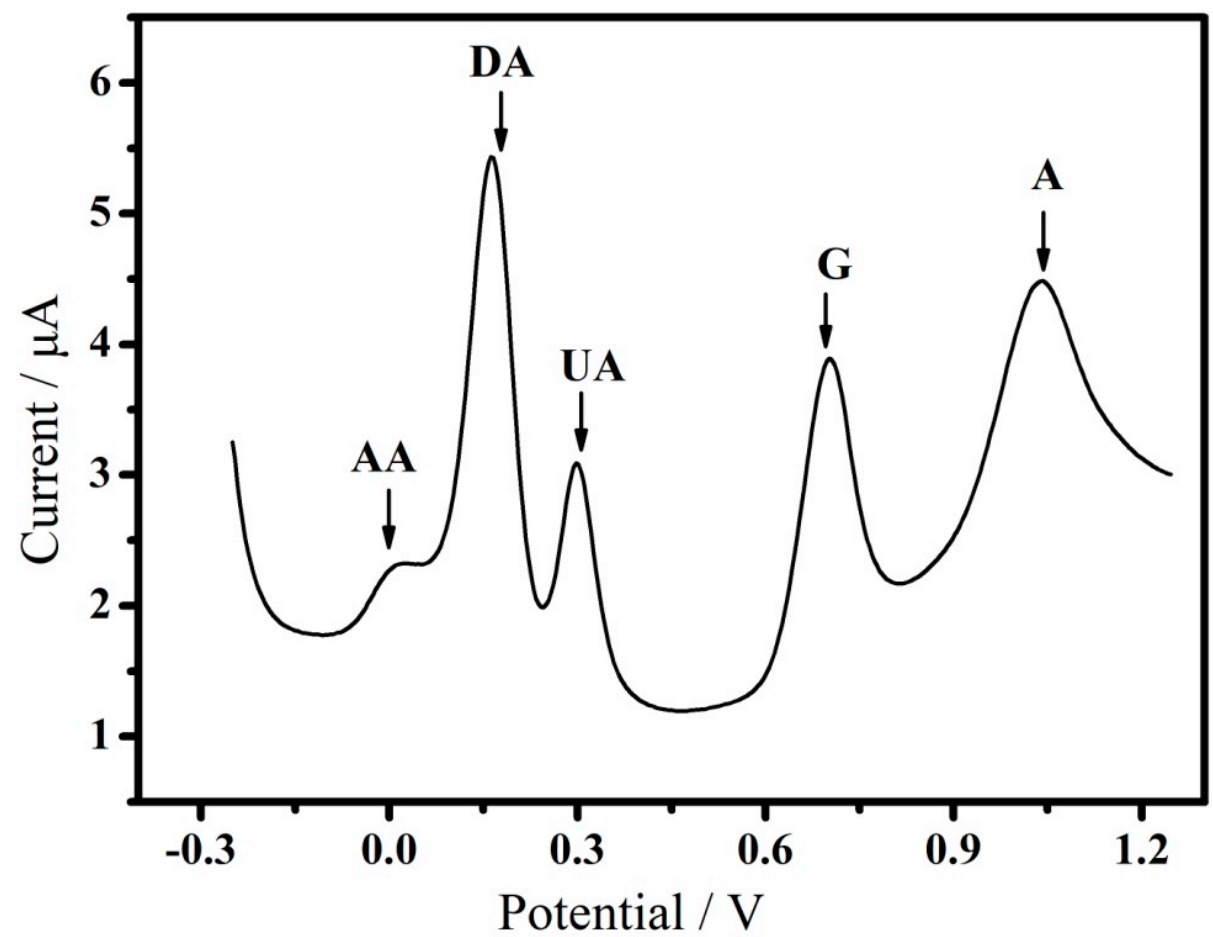

Figure 4. DPV of the mixture of five biological molecules including $200 \mu \mathrm{M} \mathrm{AA}, 10 \mu \mathrm{M}$ DA, $20 \mu \mathrm{M}$ UA, $20 \mu \mathrm{M} \mathrm{G}$, and $20 \mu \mathrm{M}$ A at screen-printed electrode modified with $\mathrm{GO}_{-0.75 \mathrm{~V}}$. Conditions are the same as in Figure 3. 


\subsection{Antibiofouling Property}

UA derives from the final metabolism of purine, which is a constituent of nucleic acids, and is finally excreted into the urine by the kidney [49]. Evaluated serum UA level (also called hyperuricemia) could lead to gout and nephrolithiasis, which has recently been found to be related to hypertension, coronary heart disease, heart failure, atrial fibrillation, insulin resistance, and nonalcoholic fatty liver disease [50]. In order to achieve the practical detection of UA in serum, the electrode should possess not only high selectivity, but also excellent antibiofouling ability. First, an $\mathrm{Fe}(\mathrm{CN})_{6}{ }^{3-/ 4-}$ redox couple was utilized to investigate the binding of electrodes with BSA and antibiofouling property (Figure 5). The electrodes before and after immersing in BSA exhibited distinct differences in $\mathrm{Fe}(\mathrm{CN})_{6}{ }^{3-/ 4-}$ solution. It is amazing to find that the current of GO-BSA/GCE is about 25 times higher than that of GO/GCE, suggesting that the BSA coating on the electrode surface does not hinder the electron transfer and mass transport. However, the current of $\mathrm{GO}_{-0.75 \mathrm{~V}^{-}}$ BSA/GCE is only about 1.8 times higher than that of $\mathrm{GO}_{-0.75 \mathrm{~V}} / \mathrm{GCE}$. The findings indicate that the oxo functionalities are beneficial for the binding of BSA, which may be caused by hydrophilic interaction and hydrogen-bonding interaction. The isoionic point of BSA is about 5 , which suggests that BSA exhibits a negative charge at $\mathrm{pH} 7.2$ because of the loss of protons from the imidazole groups of amino acids in BSA [51]. It was considered that the binding of BSA improves the electroactive area of the electrode, and the $\mathrm{Fe}(\mathrm{CN})_{6}{ }^{3-/ 4-}$ redox couple can transport freely. As a result, the redox current increased dramatically when BSA was attached to the electrode. EIS was carried out to investigate the electrochemical

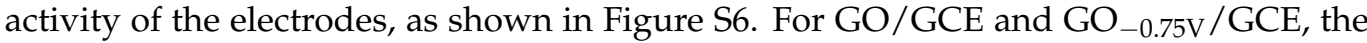
equivalent circuit fitted from the EIS includes a series combination of R1, R2, Ws, CPE1 and CPE2. The electrode surface can be considered as a graphene surface that is covered by the oxygen-containing functional species [52]. In this case, R2 and CPE1 correspond to the graphene surface without oxo functionalities, and CPE2 and Ws correspond to the oxidized surface. R1 and R2 represent the electrolyte resistance and the charge transfer resistance, respectively. Ws is a finite-length Warburg element that represents the diffusion through an oxidized graphene surface. However, additional (R3, CPE3) was observed for GO-BSA/GCE and $\mathrm{GO}_{-0.75 \mathrm{~V}}$-BSA/GCE, which is linked with the attached BSA layer. The fitted parameters for different electrodes are listed in Table S1. There is no significant change in the charge transfer resistance (R2) before and after the modification of BSA. However, diffusion resistance (W1-R) decreased when BSA was attached to the surface, indicating that the loading of BSA improved the diffusion of $\mathrm{Fe}(\mathrm{CN})_{6}{ }^{3-/ 4-}$.
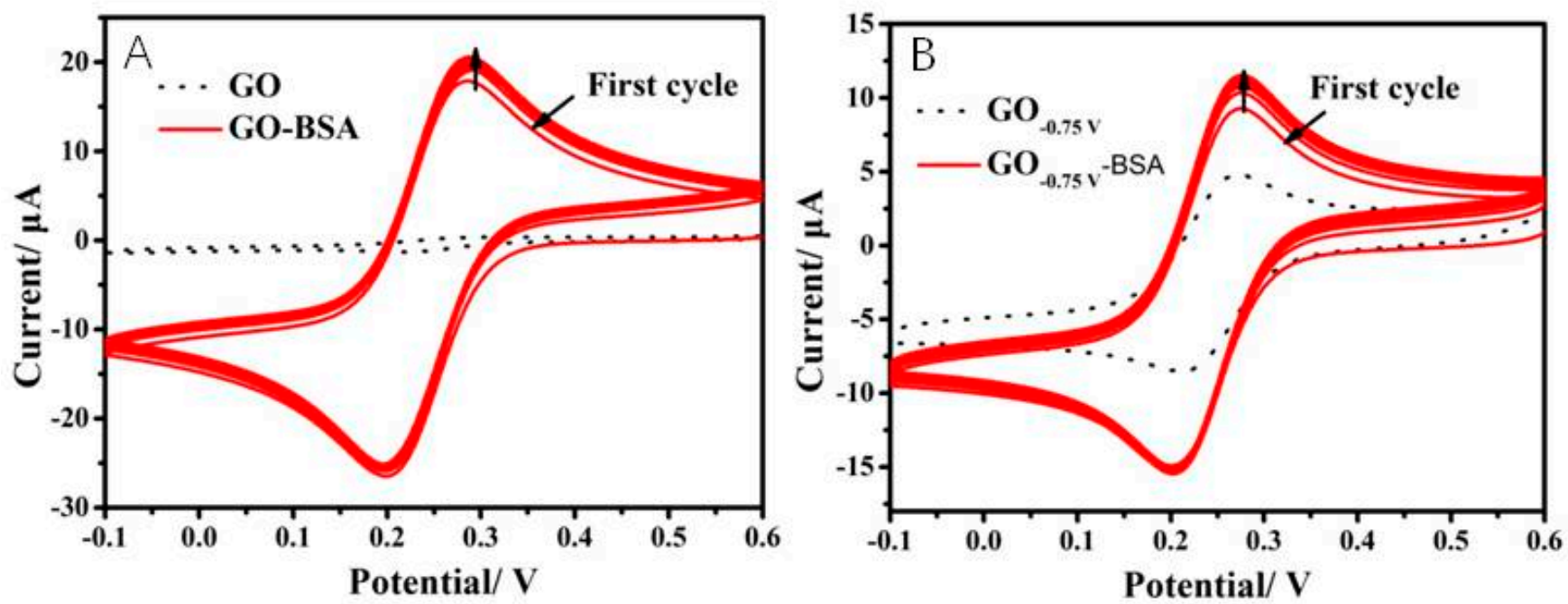

Figure 5. CVs of GO/GCE ((A), dotted line), GO-BSA/GCE ((A), solid line), GO_0.75V/GCE $\left((\mathbf{B})\right.$, dotted line), and $\mathrm{GO}_{-0.75 \mathrm{~V}}-\mathrm{BSA} / \mathrm{GCE}\left((\mathbf{B})\right.$, solid line) in $5 \mathrm{mM} \mathrm{Fe}(\mathrm{CN})_{6}{ }^{3-/ 4-}$ redox couple at the scan rate of $25 \mathrm{mV} / \mathrm{s}$. 
Similar results were found at $100 \%$ serum modified electrode due to the binding of serum proteins (Figure S7). When the potential is more negative than $-0.85 \mathrm{~V}$, the current of $\mathrm{GO}_{\text {potential }}$-serum/GCE is much lower than that of $\mathrm{GO}_{\text {potential }} / \mathrm{GCE}$. The surface morphology and composition of the electrodes and BSA-modified electrodes were also investigated by XPS (Figure 6) and SEM (Figure S8). The carbon (1 s) spectra for GO-BSA and $\mathrm{GO}_{-0.75 \mathrm{v}}$-BSA can be well fitted to three peaks, suggesting three components of carbon. The peak at $284.7 \mathrm{eV}$ was the bulk C peak ascribed to the alkyl chain. The second peak at approximately $286.4 \mathrm{eV}$ was attributed to the C-S bond, indicating that BSA might be attached to the electrode by thiol groups or disulfide (S-S) presented on BSA. The third peak located at approximately $287.9 \mathrm{eV}$ indicated amide bonds or carboxyl groups. A more clear wrinkled structure was observed for $\mathrm{GO}_{-0.75 \mathrm{~V}}$ than $\mathrm{GO}_{-0.75 \mathrm{~V}}-\mathrm{BSA} / \mathrm{GCE}$, which also indicated the attachment of BSA film (Figure S8). The antibiofouling property of the electrodes was also investigated by testing the DPV of the mixture of AA, DA, and UA at the $\mathrm{GO}_{-0.75 \mathrm{~V}} / \mathrm{GCE}, \mathrm{GO}_{-0.75 \mathrm{~V}}-\mathrm{BSA} / \mathrm{GCE}$ and $\mathrm{GO}_{-0.75 \mathrm{~V}}$-serum/GCE (Figure 7). It was found that the attached BSA did not interfere with the detection of AA, DA, and UA. However, $\mathrm{GO}_{-0.75 \mathrm{~V}}$-serum/GCE exhibited a much lower current than that of $\mathrm{GO}_{-0.75 \mathrm{~V}} / \mathrm{GCE}$, which might be caused by other species that existed in the serum. Figure S9 shows the DPV of $\mathrm{GO}_{-0.75 \mathrm{~V}} / \mathrm{GCE}, \mathrm{GO}_{-0.75 \mathrm{v}}$-BSA/GCE, $\mathrm{GO}_{-0.75 \mathrm{~V}}$-serum/GCE and $\mathrm{GO}_{-0.75 \mathrm{~V}}$-BSA-UA/GCE in background electrolyte (0.1 M pH 7.2 PBS). An obvious oxidation peak of UA was observed, indicating that UA could be attached to BSA [53].
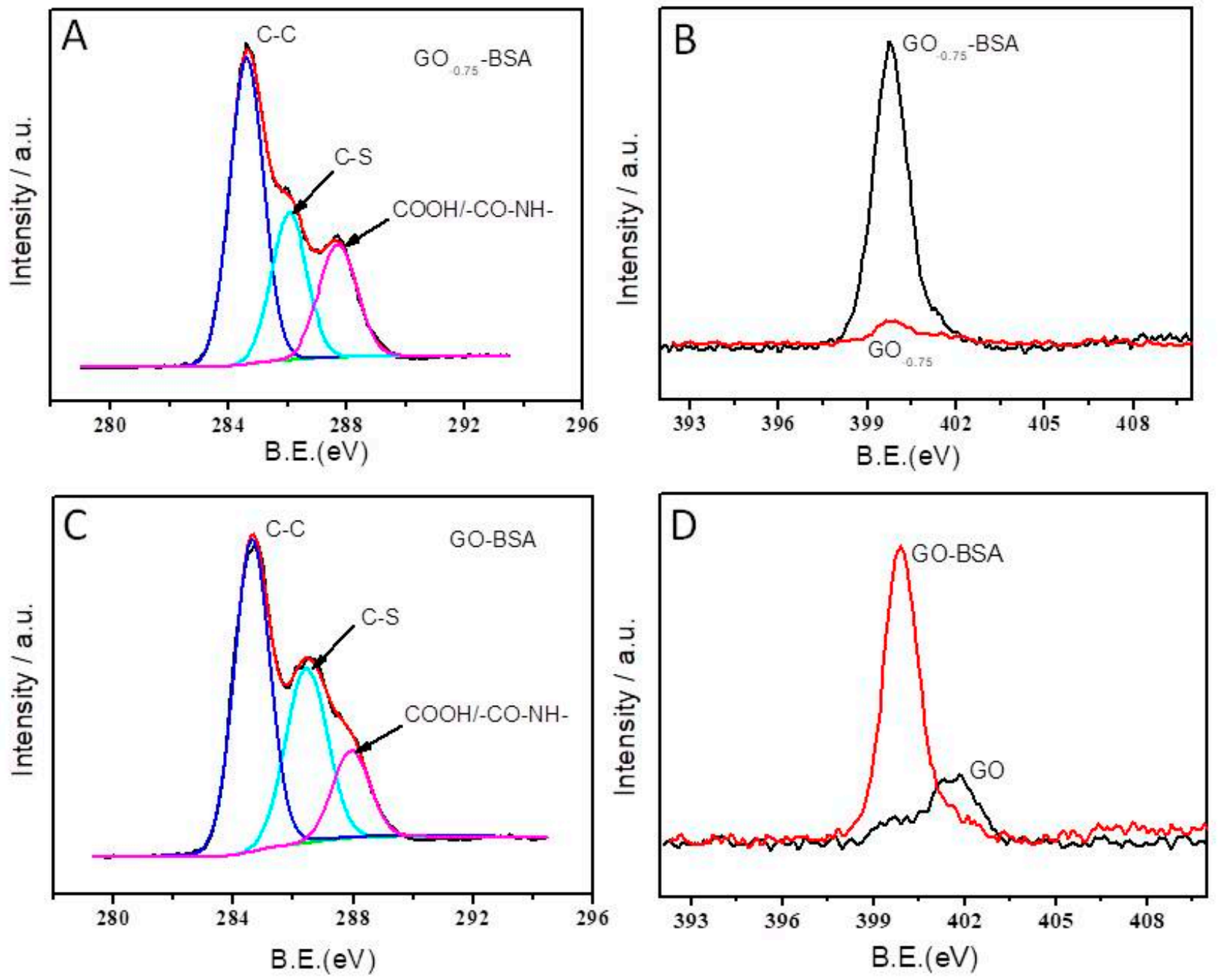

Figure 6. XPS narrow scan of the $\mathrm{C} 1 \mathrm{~s}(\mathbf{A}, \mathbf{C})$ and N1s $(\mathbf{B}, \mathbf{D})$ region for $\mathrm{GO}(\mathbf{D}), \mathrm{GO}_{-0.75 \mathrm{~V}}(\mathbf{B}), \mathrm{GO}_{-0.75 \mathrm{~V}}-\mathrm{BSA}$ $(\mathbf{A}, \mathbf{B})$ and GO-BSA $(\mathbf{C}, \mathbf{D})$. 


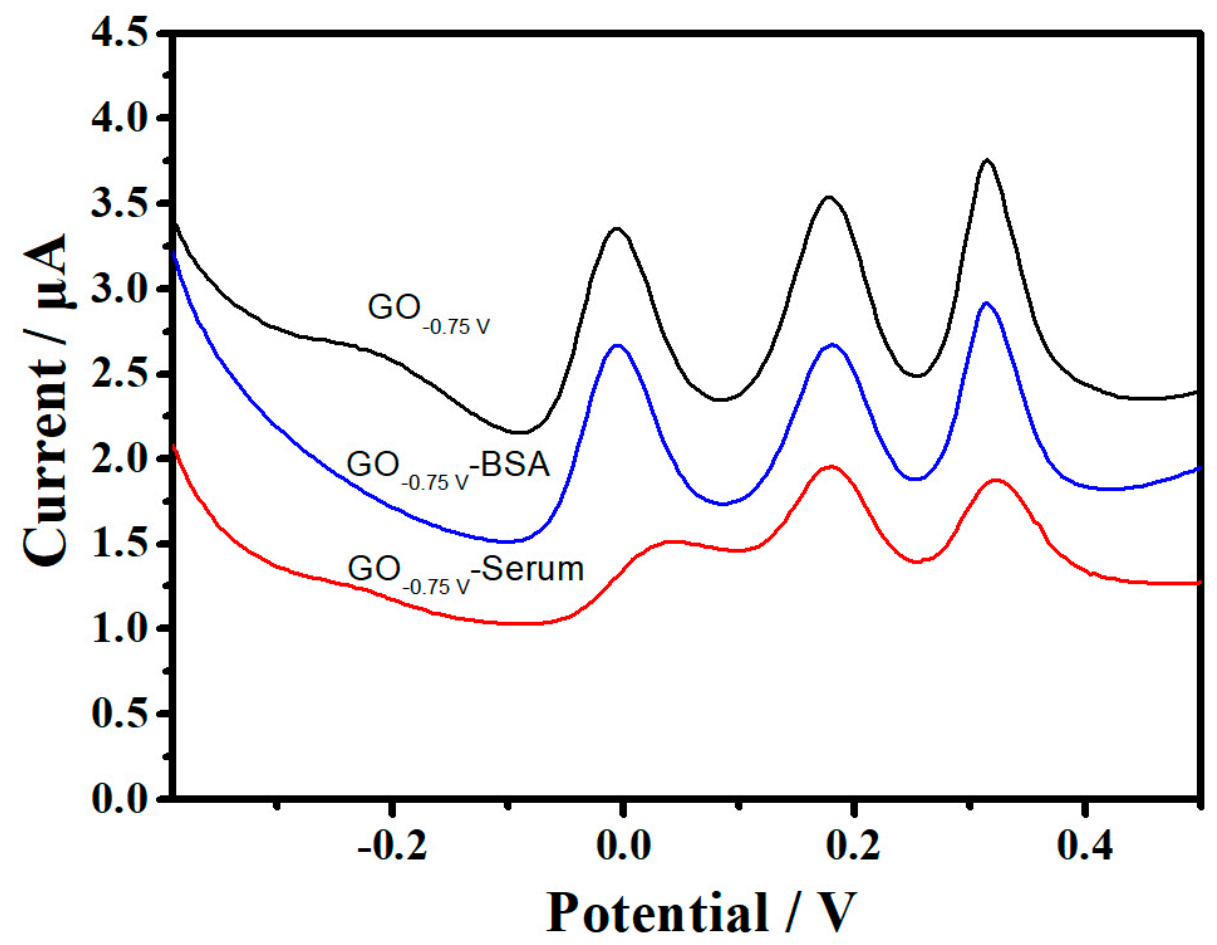

Figure 7. DPV of the mixture of AA, DA, and UA in $0.1 \mathrm{M} \mathrm{pH} 7.2 \mathrm{PBS}$ at the GO_0.75V/GCE, $\mathrm{GO}_{-0.75 \mathrm{~V}}$-BSA/GCE and $\mathrm{GO}_{-0.75 \mathrm{~V}}$-serum/GCE. Conditions are the same as in Figure 3.

\subsection{Analysis of UA in Serum}

The GO-based electrochemical sensor was tested to demonstrate the capacity for the detection of UA in practical human serum samples through a standard addition method (Figure S10). The serum sample was diluted with PBS at a 1:40 $v / v$ ratio for direct measurement without any other pretreatment. The detected content of UA in real serum was $160 \mu \mathrm{M}$, which is much lower than that $(220 \mu \mathrm{M})$ obtained by the commercial clinical method.

\section{Conclusions}

A micro electrochemical sensor was developed for multi-analyte detection based on the electrochemically tuned GO electrode. The key problem of biofouling was investigated and discussed in detail. The results showed that the oxo functionalities present on GO played an important role in electrocatalysis, selectivity, and antibiofouling performance. In this work, we presented a low-cost and simple electrode that possessed both excellent antibiofouling performance and high electrocatalytic activity toward the multi-analyte. Electroactive probe investigation indicated that the attachment of BSA did not hinder the electron transfer but enhanced the diffusion of probes. This electrode was demonstrated to detect the real content of UA in a serum sample. This simple method will provide a promising potential in clinical application.

Supplementary Materials: The following supporting information can be downloaded at: https: / / www.mdpi.com/article/10.3390/nano12040711/s1, Figure S1: Electrochemical detection of UA in the presence of AA and DA at GO-0.75 V/GCE in 0.1 M pH 7.2 PBS. Inset: calibration plot for the peak current versus UA concentrations. Conditions: Inc E, 4 mV; Amplitude, 0.05 V; Pulse width, 0.2 s; Sample width, $0.0167 \mathrm{~s}$; Pulse period, $0.5 \mathrm{~s}$; Figure S2: Electrochemical detection of DA in the presence of AA and UA at GO-0.75 V/GCE in $0.1 \mathrm{M} \mathrm{pH} \mathrm{7.2} \mathrm{PBS.} \mathrm{Inset:} \mathrm{calibration} \mathrm{plot} \mathrm{for} \mathrm{the} \mathrm{peak} \mathrm{current}$ versus DA concentrations; Figure S3: DPV of the mixture of G and A in $0.1 \mathrm{M} \mathrm{pH} 7.2 \mathrm{PBS}$ at the GCE, GO, and GO/GCE electrochemically treated at different potentials; Figure S4: Electrochemical detection of $\mathrm{G}$ in the presence of $\mathrm{A}$ at GO-0.75 V/GCE in 0.1 M pH 7.2 PBS. Inset: calibration plot for the peak current versus $\mathrm{G}$ concentrations; Figure S5: Electrochemical detection of $\mathrm{A}$ in the presence of $\mathrm{G}$ at GO-0.75 V/GCE in 0.1 M pH 7.2 PBS. Inset: calibration plot for the peak current versus A 
concentrations; Figure S6: Nyquist diagrams (A and C) and phase angle diagrams vs log of frequency of Bode plots (B and D) for different electrodes. The symbols and solid lines present the experimental and the fitted data, respectively. The insets in phase angle diagrams are the corresponding electrical equivalent circuits. EIS was carried out in $0.1 \mathrm{M} \mathrm{KCl}$ containing $5 \mathrm{mM} \mathrm{Fe}(\mathrm{CN})_{6}{ }^{3-/ 4-}$ in the frequency range from $1 \mathrm{MHz}$ to $0.1 \mathrm{~Hz}$ at $0.24 \mathrm{~V}$; Figure S7: $\mathrm{CVs}$ of $5 \mathrm{mM} \mathrm{Fe}(\mathrm{CN})_{6}{ }^{3-/ 4-}$ redox couple at different GOpotential /GCE (dotted line) and GOpotential-serum /GCE (solid line) at the scan rate of $25 \mathrm{mV} / \mathrm{s}$. A: GO, B: GO-0.6 V, C: GO-0.65 V, D: GO-0.75 V, E:GO-0.85 V, F:GO-0.95 V; Figure S8: SEM images of GO-0.75 V/GCE (A) and GO-0.75 V-BSA/GCE (B); Figure S9: DPV of GO-0.75 V/GCE, GO-0.75 V-BSA/GCE, GO-0.75 V-serum/GCE and GO-0.75 V-BSA-UA/GCE in background electrolyte $(0.1 \mathrm{M}$ pH 7.2 PBS); Figure S10: Standard addition method for the measurement of UA in 40-folds diluted serum; Table S1: Obtained parameters from fitting for different electrodes.

Author Contributions: Conceptualization, B.Y.; Data curation, B.Y., L.G. and C.X.; Formal Analysis, B.Y.; Funding acquisition, B.Y.; Investigation, L.G., B.Y. and G.L. (Gang Li); Methodology, B.Y.; Project administration, B.Y. and C.X.; Supervision, B.Y.; Validation, B.Y. and L.G.; Visualization, B.Y. and L.G.; Writing — original draft, B.Y.; Writing—review \& editing, B.Y. and G.L. (Gang Liu). All authors have read and agreed to the published version of the manuscript.

Funding: This research was funded by the Natural Science Foundation of Shandong Province, China (No.ZR2020MB058).

Institutional Review Board Statement: Not applicable.

Informed Consent Statement: Not applicable.

Data Availability Statement: The authors confirm that the data supporting the findings of this study are available within the article [and/or] its supplementary materials.

Acknowledgments: This work was funded by the Natural Science Foundation of Shandong Province (No.ZR2020MB058).

Conflicts of Interest: The authors declare no conflict of interest.

\section{Abbreviations}

\begin{tabular}{|c|c|}
\hline PB & Prussian blue \\
\hline TiN-rGO & titanium nitride-reduced graphene oxide \\
\hline N-rGO & nitrogen-doped reduced graphene oxide \\
\hline PVP & polyvinylpyrrolidone \\
\hline GR & graphene \\
\hline h-BN & hexagonal boron nitride \\
\hline $\mathrm{PrGO} / \mathrm{MnO}_{2}$ & poly(3,4-ethylenedioxythiophene)/reduced graphene oxide/manganese dioxide \\
\hline AuNPs & gold nanoparticles \\
\hline MNP & magnetic nanoparticles \\
\hline ERGO-pEBT & electrochemically reduced graphene oxide-poly(eriochrome black T) \\
\hline HCONS & hexagonal cobalt oxide nanosheets \\
\hline $\mathrm{Ni@CHS/rGO}$ & Ni@carbon hollow nanosphere/reduced graphene oxide \\
\hline PGE & pencil graphite electrode \\
\hline PPyox & polypyrrole \\
\hline p-GLY/GO & poly(glycine)/graphene oxide composite based sensor \\
\hline CQD/PAPox & carbon quantum dots (CQDs) and overoxidized poly(2-aminopyridine) (PAPox) \\
\hline$\beta C D / I R G O$ & $\beta$-cyclodextrin functionalized reduced graphite oxide with the aid of ionic liquid \\
\hline CTME & carbon-thread microelectrode \\
\hline
\end{tabular}

\section{References}

1. Del Río, J.S.; Henry, O.Y.; Jolly, P.; Ingber, D.E. An antifouling coating that enables affinity-based electrochemical biosensing in complex biological fluids. Nat. Nanotechnol. 2019, 14, 1143-1149. [CrossRef] [PubMed]

2. Jiang, C.; Wang, G.; Hein, R.; Liu, N.; Luo, X.; Davis, J.J. Antifouling strategies for selective in vitro and in vivo sensing. Chem. Rev. 2020, 120, 3852-3889. [CrossRef] [PubMed]

3. Barfidokht, A.; Gooding, J.J. Approaches toward allowing electroanalytical devices to be used in biological fluids. Electroanalysis 2014, 26, 1182-1196. [CrossRef] 
4. $\quad$ Russo, M.J.; Han, M.; Desroches, P.E.; Manasa, C.S.; Dennaoui, J.; Quigley, A.F.; Kapsa, R.M.I.; Moulton, S.E.; Guijt, R.M.; Greene, G.W.; et al. Antifouling strategies for electrochemical biosensing: Mechanisms and performance toward point of care based diagnostic applications. ACS Sens. 2021, 6, 1482-1507. [CrossRef]

5. Silva, T.A.; Khan, M.R.K.; Fatibello-Filho, O.; Collinson, M.M. Simultaneous electrochemical sensing of ascorbic acid and uric acid under biofouling conditions using nanoporous gold electrodes. J. Electroanal. Chem. 2019, 846, 113160. [CrossRef]

6. Brisebois, P.P.; Siaj, M. Harvesting graphene oxide-years 1859 to 2019: A review of its structure, synthesis, properties and exfoliation. J. Mater. Chem. C 2020, 8, 1517-1547. [CrossRef]

7. Kim, J.; Cote, L.J.; Kim, F.; Yuan, W.; Shull, K.R.; Huang, J. Graphene oxide sheets at interfaces. J. Am. Chem. Soc. 2010, 132, 8180-8186. [CrossRef]

8. Joshi, D.J.; Koduru, J.R.; Malek, N.I.; Hussain, C.M.; Kailasa, S.K. Surface modifications and analytical applications of graphene oxide: A review. Trac-Trend. Anal. Chem. 2021, 144, 116448. [CrossRef]

9. Agarwal, V.; Zetterlund, P.B. Strategies for reduction of graphene oxide-A comprehensive review. Chem. Eng. J. 2021, 405,127018 [CrossRef]

10. Lavin-Lopez, M.D.P.; Paton-Carrero, A.; Sanchez-Silva, L.; Valverde, J.L.; Romero, A. Influence of the reduction strategy in the synthesis of reduced graphene oxide. Adv. Powder Technol. 2017, 28, 3195-3203. [CrossRef]

11. Renteria, J.A.Q.; Ruiz-Garcia, C.; Sauvage, T.; Chazaro-Ruiz, L.F.; Rangel-Mendez, J.R.; Ania, C.O. Photochemical and electrochemical reduction of graphene oxide thin films: Tuning the nature of surface defects. Phys. Chem. Chem. Phys. 2020, 22, 20732-20743. [CrossRef] [PubMed]

12. Kim, H.W.; Ross, M.B.; Kornienko, N.; Zhang, L.; Guo, J.; Yang, P.; McCloskey, B.D. Efficient hydrogen peroxide generation using reduced graphene oxide-based oxygen reduction electrocatalysts. Nat. Catal. 2018, 1, 282-290. [CrossRef]

13. Tan, X.; Tahini, H.A.; Smith, S.C. Understanding the high activity of mildly reduced graphene oxide electrocatalysts in oxygen reduction to hydrogen peroxide. Mater. Horiz. 2019, 6, 1409-1415. [CrossRef]

14. Kim, H.W.; Park, H.; Roh, J.S.; Shin, J.E.; Lee, T.H.; Zhang, L.; McCloskey, B.D. Carbon defect characterization of nitrogen-doped reduced graphene oxide electrocatalysts for the two-electron oxygen reduction reaction. Chem. Mater. 2019, 31, 3967-3973. [CrossRef]

15. Yuan, B.; Zeng, X.; Xu, C.; Liu, L.; Ma, Y.; Zhang, D.; Fan, Y. Electrochemical modification of graphene oxide bearing different types of oxygen functional species for the electro-catalytic oxidation of reduced glutathione. Sens. Actuators B-Chem. 2013, 184, 15-20. [CrossRef]

16. Zhang, D.; Xu, C.; Li, S.; Zhang, R.; Yan, H.; Miao, H.; Yong, F.; Yuan, B. Electrochemically controlling oxygen functional groups in graphene oxide for the optimization in the electro-catalytic oxidation of dihydroxybenzene isomers and L-methionine. J. Electroanal. Chem. 2014, 717, 219-224. [CrossRef]

17. Uhm, S.; Tuyen, N.H.; Lee, J. Controlling oxygen functional species of graphene oxide for an electro-oxidation of L-ascorbic acid Electrochem. Commun. 2011, 13, 677-680. [CrossRef]

18. Hui, K.H.; Ambrosi, A.; Pumera, M.; Bonanni, A. Improving the analytical performance of graphene oxide towards the assessment of polyphenols. Chem.-Eur. J. 2016, 22, 3830-3834. [CrossRef]

19. Maccaferri, G.; Zanardi, C.; Xia, Z.Y.; Kovtun, A.; Liscio, A.; Teizi, F.; Palermo, V.; Seeber, R. Systematic study of the correlation between surface chemistry, conductivity and electrocatalytic properties of graphene oxide nanosheets. Carbon 2017, 120, 165-175. [CrossRef]

20. Zheng, L.; Wu, S.; Lin, X.; Nie, L.; Rui, L. Selective determination of uric acid by using a $\beta$-cyclodextrin modified electrode. Electroanalysis 2001, 13, 1351-1354. [CrossRef]

21. Zen, J.M.; Chen, P.J. A selective voltammetric method for uric acid and dopamine detection using clay-modified electrodes. Anal. Chem. 1997, 69, 5087-5093. [CrossRef]

22. Dos Santos, P.L.; Katic, V.; Toledo, K.C.F.; Bonacin, J.A. Photochemical one-pot synthesis of reduced graphene oxide/Prussian blue nanocomposite for simultaneous electrochemical detection of ascorbic acid, dopamine, and uric acid. Sens. Actuators B-Chem. 2018, 255, 2437-2447. [CrossRef]

23. Feng, J.; Li, Q.; Cai, J.P.; Yang, T.; Chen, J.H.; Hou, X.M. Electrochemical detection mechanism of dopamine and uric acid on titanium nitride-reduced graphene oxide composite with and without ascorbic acid. Sens. Actuators B-Chem. 2019, $298,126872$. [CrossRef]

24. Wu, Y.; Deng, P.; Tian, Y.; Feng, J.; Xiao, J.; Li, J.; Liu, J.; Li, G.; He, Q. Simultaneous and sensitive determination of ascorbic acid, dopamine and uric acid via an electrochemical sensor based on PVP-graphene composite. J. Nanobiotechnol. 2020, 18, 112. [CrossRef]

25. Li, Q.; Huo, C.R.; Yi, K.; Zhou, L.L.; Su, L.; Hou, X.M. Preparation of flake hexagonal BN and its application in electrochemical detection of ascorbic acid, dopamine and uric acid. Sens. Actuators B-Chem. 2018, 260, 346-356. [CrossRef]

26. Tukimin, N.; Abdullah, J.; Sulaiman, Y. Electrodeposition of poly(3,4-ethylenedioxythiophene)/reduced graphene oxide/manganese dioxide for simultaneous detection of uric acid, dopamine and ascorbic acid. J. Electroanal. Chem. 2018, 820, 74-81. [CrossRef]

27. Huang, Y.Q.; Zang, Y.; Ruan, S.J.; Zhang, Y.Y.; Gao, P.P. A high efficiency N, P doped porous carbon nanoparticles derived from lotus leaves for simultaneous electrochemical determination of ascorbic acid, dopamine, and uric acid. Microchem. J. 2021, 165, 106152. [CrossRef] 
28. Zhang, H.Y.; Liu, S. Electrochemical sensors based on nitrogen-doped reduced graphene oxide for the simultaneous detection of ascorbic acid, dopamine and uric acid. J. Alloys Compd. 2020, 842, 155873. [CrossRef]

29. Lee, C.S.; Yu, S.H.; Kim, T.H. One-step electrochemical fabrication of reduced graphene oxide/gold nanoparticles nanocompositemodified electrode for simultaneous detection of dopamine, ascorbic acid, and uric acid. Nanomaterials 2017, 8, 17. [CrossRef]

30. Rosli, A.R.M.; Yusoff, F.; Loh, S.H.; Yusoff, H.M.; Jamil, M.M.A.; Shamsudin, S.H. Simultaneous electrochemical detection of ascorbic acid, dopamine, and uric acid at magnetic nanoparticles/reduced graphene oxide modified electrode. J. Teknol. 2021, 83, 85-92. [CrossRef]

31. Mohammed, N.; Abdullah, J.; Kamaruzaman, S.; Saiman, M.; Sulaiman, Y. Electrochemical reduced graphene oxidepoly(eriochrome black T)/gold nanoparticles modified glassy carbon electrode for simultaneous determination of ascorbic acid, dopamine and uric acid. Arab. J. Chem. 2018, 11, 1301-1312. [CrossRef]

32. Minta, D.; Gonzalez, Z.; Wiench, P.; Gryglewicz, S.; Gryglewicz, G. N-Doped reduced graphene oxide/gold nanoparticles composite as an improved sensing platform for simultaneous detection of dopamine, ascorbic acid, and uric acid. Sensors 2020, 20, 4427. [CrossRef] [PubMed]

33. Zahed, M.A.; Barman, S.C.; Toyabur, R.M.; Sharifuzzaman, M.; Xuan, X.; Nah, J.; Park, J.Y. Ex situ hybridized hexagonal cobalt oxide nanosheets and RGO@MWCNT based nanocomposite for ultra-selective electrochemical detection of ascorbic acid, dopamine, and uric Acid. J. Electrochem. Soc. 2019, 166, B304-B311. [CrossRef]

34. Zhang, L.; Zhang, J. 3D hierarchical bayberry-like Ni@carbon hollow nanosphere/rGO hybrid as a new interesting electrode material for simultaneous detection of small biomolecules. Talanta 2018, 178, 608-615. [CrossRef] [PubMed]

35. Vishnu, N.; Badhulika, S. Single step grown $\mathrm{MoS}_{2}$ on pencil graphite as an electrochemical sensor for guanine and adenine: A novel and low cost electrode for DNA studies. Biosens. Bioelectron. 2018, 124, 122-128. [CrossRef] [PubMed]

36. Geng, X.T.; Bao, J.; Huang, T.; Wang, X.J.; Hou, C.J.; Hou, J.Z.; Samalo, M.; Yang, M.; Huo, D.Q. Electrochemical Sensor for the Simultaneous Detection of Guanine and Adenine Based on a PPyox/MWNTs-MoS 2 Modified Electrode. J. Electrochem. Soc. 2019, 166, B498-B504. [CrossRef]

37. Wang, D.; Huang, B.; Liu, J.; Guo, X.; Abudukeyoumu, G.; Zhang, Y.; Ye, B.C.; Li, Y. A novel electrochemical sensor based on $\mathrm{Cu} @ \mathrm{Ni} / \mathrm{MWCNTs}$ nanocomposite for simultaneous determination of guanine and adenine. Biosens. Bioelectron. 2018, 102, 389-395. [CrossRef]

38. Arvand, M.; Sanayeei, M.; Hemmati, S. Label-free electrochemical DNA biosensor for guanine and adenine by ds-DNA/poly(Lcysteine)/Fe3O4 nanoparticles-graphene oxide nanocomposite modified electrode. Biosens. Bioelectron. 2018, 102, 70-79. [CrossRef]

39. He, S.; He, P.; Zhang, X.; Zhang, X.; Liu, K.; Jia, L.; Dong, F. Poly(glycine)/graphene oxide modified glassy carbon electrode: Preparation, characterization and simultaneous electrochemical determination of dopamine, uric acid, guanine and adenine. Anal. Chim. Acta 2018, 1031, 75-82. [CrossRef]

40. Zhang, S.; Zhuang, X.; Chen, D.; Luan, F.; He, T.; Tian, C.; Chen, L. Simultaneous voltammetric determination of guanine and adenine using $\mathrm{MnO} 2$ nanosheets and ionic liquid-functionalized graphene combined with a permeation-selective polydopamine membrane. Microchim. Acta 2019, 186, 1-10. [CrossRef]

41. Siddegowda, K.; Mahesh, N.B.; Kumara, S. Fabrication of copper oxide nanoparticles modified carbon paste electrode and its application in simultaneous electroanalysis of guanine, adenine and thymine. Sens. Actuators A-Phys. 2018, 280, $277-286$.

42. Zhao, X.; Guo, H.; Xue, R.; Wang, M.Y.; Guan, Q.X.; Fan, T.; Yang, W.H.; Yang, W. Electrochemical sensing and simultaneous determination of guanine and adenine based on covalent organic frameworks/NH2-rG/MoS2 modified glassy carbon electrode. Microchem. J. 2021, 160, 105759. [CrossRef]

43. Gao, S.H.; Li, H.J.; Li, M.J.; Li, C.P.; Qian, L.R.; Yang, B.H. A gold-nanoparticle/horizontal-graphene electrode for the simultaneous detection of ascorbic acid, dopamine, uric acid, guanine, and adenine. J.Solid State Electrochem. 2018, 22, 3245-3254. [CrossRef]

44. He, S.; He, P.; Zhang, X.; Zhang, X.; Dong, F.; Jia, L.; Du, L.; Lei, H. Simultaneous voltammetric determination of guanine and adenine by using a glassy carbon electrode modified with a composite consisting of carbon quantum dots and overoxidized poly(2-aminopyridine). Microchim. Acta 2018, 185, 107. [CrossRef]

45. Aktürk, M.; Karabiberoğlu, S.U.; Dursun, Z. Fabrication of $\mathrm{Cu}-\mathrm{CeO}_{2}$ coated multiwall carbon nanotube composite electrode for simultaneous determination of guanine and adenine. Electroanalysis 2018, 30, 238-249. [CrossRef]

46. Mahanthappa, M.; Kottam, N.; Yellappa, S. Electrocatalytic performance of a zinc sulphide nanoparticles-modified carbon paste electrode for the simultaneous determination of acetaminophen, guanine and adenine. Anal. Methods 2018, 10, 1362-1371. [CrossRef]

47. Wang, M.L.; Cui, M.Z.; Liu, W.F.; Liu, X.G.; Xu, B.S. Facile Synthesis of Cyclodextrin Functionalized Reduced Graphite Oxide with the Aid of Ionic Liquid for Simultaneous Determination of Guanine and Adenine. Electroanalysis 2018, 30, 842-851. [CrossRef]

48. Zhang, N.; Zhong, W.L.; Zhang, Z.Q.; Fan, Y.W. Electrochemical behaviours of guanine and adenine and their simultaneous determination using a three-dimensional porous poly(dopamine)/Reduced Graphene Oxide-Modified Electrode. Int. J. Electrochem. Sci. 2020, 15, 5287-5295. [CrossRef]

49. Kim, I.; Im Kim, Y.; Lee, S.W.; Jung, H.G.; Lee, G.; Yoon, D.S. Highly permselective uric acid detection using kidney cell membrane-functionalized enzymatic biosensors. Biosens. Bioelectron. 2021, 190, 113411. [CrossRef]

50. Lee, S.J.; Oh, B.K.; Sung, K.C. Uric acid and cardiometabolic diseases. Clin. Hypertens. 2020, 26, 1-7. [CrossRef] 
51. Zhou, L.; Wang, K.; Wu, Z.; Dong, H.; Sun, H.; Cheng, X.; Zhang, H.; Zhou, H.; Jia, C.; Jin, Q.; et al. Investigation of controllable nanoscale heat-denatured bovine serum albumin films on graphene. Langmuir 2016, 32, 12623-12631. [CrossRef] [PubMed]

52. Casero, E.; Parra-Alfambra, A.M.; Petit-Domínguez, M.D.; Pariente, F.; Lorenzo, E.; Alonso, C. Differentiation between graphene oxide and reduced graphene by electrochemical impedance spectroscopy (EIS). Electrochem. Commun. 2012, 20, 63-66. [CrossRef]

53. Makarska-Bialokoz, M.; Lipke, A. Study of the binding interactions between uric acid and bovine serum albumin using multiple spectroscopic techniques. J. Mol. Liq. 2019, 276, 595-604. [CrossRef] 